International Journal of Social Science (IJSS)

Vol.1 Issue.5 February 2022, pp: 569-574

ISSN: 2798-3463 (Printed) | 2798-4079 (Online)

\title{
THE URGENCY OF CULTURAL REVITALIZATION IN THE INDONESIA-MALAYSIA BORDER REGION
}

\author{
By \\ Ersa Tri Fitriasari \\ Human Resources Development Agency of West Kalimantan Province, Indonesia \\ Email: ersa3.dhobithoh@gmail.com
}

\begin{tabular}{l}
\hline \hline Article Info \\
\hline Articlehistory: \\
Received Nov 9, 2021 \\
Revised Dec 26, 2021 \\
Accepted Jan 16, 2021
\end{tabular}

Keywords:

Poverty, Welfare, Nationalism

\begin{abstract}
This study focuses on the cultural revitalization aspect as an urgent matter in the Indonesia-Malaysia border region, SajinganBesar Sub-district, Sambas Regency. The results of this study can be summarized that the main problem of cultural development in the border region is not only caused by globalization but also concerns on the condition of cultural resilience of the border communities themselves who have experienced stagnation which is from the conditions that are completely and inevitably marginal of Globalization, then it must be anticipated with cultural development that is characterized by the reinforcement of identity and local wisdom of the border community which is used as the basis for arranging strategies in preserving and developing culture. This study used a qualitative approach that was carried out by survey data, observation, analysis and FGD (Forum Group Discussion). This method is very effective for something that is urgent and important and will provide an increase in the welfare of the community whose life is generally less prosperous. Moreover, geopolitically, the cultural revitalization will further ensure the realization of the revitalization policy of the culture of the Indonesian Archipelago in the border region which can create nationalism, and maintain the border region from foreign infiltration as well as become a space for conflict resolution to create peace between countries. This study focuses on the cultural revitalization aspect as an urgent matter in the Indonesia-Malaysia border region, Sajingan Besar Sub-district, Sambas Regency. The results of this study can be summarized that the main problem of cultural development in the border region is not only caused by globalization but also concerns on the condition of cultural resilience of the border communities themselves who have experienced stagnation which is from the conditions that are completely and inevitably marginal of Globalization, then it must be anticipated with cultural development that is characterized by the reinforcement of identity and local wisdom of the border community which is used as the basis for arranging strategies in preserving and developing culture. This study used a qualitative approach that was carried out by survey data, observation, analysis and FGD (Forum Group Discussion). This method is very effective for something that is urgent and important and will provide an increase in the welfare of the community whose life is generally less prosperous. Moreover, geopolitically, the cultural revitalization will further ensure the realization of the revitalization policy of the culture of the Indonesian Archipelago in the border region which can create nationalism, and maintain the border region from foreign infiltration as well as become a space for conflict resolution to create peace between countries.
\end{abstract}

Thisisan open accessarticleundertheCC BY-SAlicense.

CorrespondingAuthor:

Ersa Tri Fitriasari

Human Resources Development Agency of West Kalimantan Province,

Indonesia

Email: ersa3.dhobithoh@gmail.com 


\section{INTRODUCTION}

From the policy perspective, the local government has an important role to play in promoting and preserving culture in the border region that is sustainable, which is by continuously building public facilities and infrastructure including the medium for channeling the culture of the local community. The current condition that has happened is that the erosion of Salako and Bakati culture which has caused the fading of cultural heritage, in the future can not be enjoyed by the next generation. Therefore, it is necessary to do cultural revitalization so that the culture of Salako and Bakati 'maintained its authenticity and sustainability. The authenticity of ancestral heritage can be maintained and is sustainable [1] and steps to protect and prevent the degradation of cultural heritage[2]. By cultural revitalization as steps for data collection and as an introduction of the work of ancestral heritage as well as preventing forgetfulness by recalling the local culture in the border region. This is very important for the development of civilization. As said by [3] culture is the fundamental of life which consists of knowledge, belief, art, law, morals, habit and so forth. Meanwhile, [4]defines culture as all human effort in viewing, interpreting, and penetrating things into something that is directed and aimed.

In this context, the existence of revitalized culture is as a realignment of local cultural values whichperhapshave a lot of deviations among the cultural adherents, these deviations can be reviewed from the perspectives of religion, social, education, economics, and society, so that the existence of these cultures is notone party on the one side and profitable on the other side.

This becomes an indicator that cultural revitalization must be upheld and the importance of management to detect buried cultural heritage, this is in line with [5]. Culture as a medium of ancestral heritage and remain sustainable with values that can be run and understood by anyone and is able to accommodate either all elements of religion, education, social, or economic. Therefore, the running of culture is in line with these elements and not opposite with these elements. Moreover, culture should also be used as an improvement of welfare in the economy, education, and social politic.

The aim of the cultural revitalization of the border region is to regrow the important values of cultural heritage with a new adjustment that does not contradict the principle of preservation and cultural values of the local community. Some questions will be answered, namely why the urgency of cultural revitalization in the IndonesiaMalaysia border region and how the development of revitalization provides benefits to improve the life quality of the community.

\section{METHODS}

Based on the results of the research and preliminary survey as well as reference study on the policy document, literature study, it was confirmed that the Urgency of Cultural Revitalization in the Border Region at the location of this research faced some problems, namely in terms of the policy, there was lack of attention from the government and the management efforts had not been carried out optimally.

The technique used in analyzing data could be visualized as follows. The analysis process in this research was carried out in some steps: the data that were obtained from the interview, focus group discussion, observation, and documentation were recorded in the field note, namely descriptive.

\section{RESULTS AND DISCUSSION}

The border area of the SajinganBesar Sub-district is mostly located in a protected forest with biodiversity with potential cultural diversity. In practice, the community still carries out the beliefs of ancestors or forefathers in preserving nature and biodiversity by maintaining the local traditions [6]. The Dayak Salako and Dayak Bakati ethnic have cultural potentials, but they have not been managed optimally and with Malaysia as an allied country that has a kinship with these ethnicities. [7]state that the border region of the SajinganBesar Sub-district is strategic. The position of the border region, especially in the SajinganBesar Sub-district is very potential and prospective to be developed to utilize natural and human resources. Heritage buildings from the local ethnic beliefs are lack of maintenance [8]. The border region of the SajinganBesar Sub-district has varied artistic and cultural potential. This can be knowledge and technology to preserve culture and tradition[9].

The community in carrying out their life routine cannot be separated from Neolithic religious practices which are inherited by their ancestors, especially in interactions with nature and the environment [10]. The cultural arts of Dayak Salako and Dayak Bakati face challenges with the presence of globalization so that it is necessary to have a strategy to revitalize traditional arts to keep up with the value of ancestral authenticity. Traditional art has been an expression of communities to support and create harmony between humans and their environment, consequently, they must adapt to market needs in line with the demands of globalization [11]. The demand for the globalization world is to maintain social collectivity, yet it experiences obstacles in the process of inheritance of traditions, which is the fading of cultural identity. The existence of Dayak Salako and Dayak Bakati 'in the 
International Journal of Social Science (IJSS)

Vol.1 Issue.5 February 2022, pp: 569-574

ISSN: 2798-3463 (Printed) | 2798-4079 (Online)

Indonesia-Malaysia border region becomes one of the strategies to strengthen the tie between countries, given the culture that belongs between allied countries, with characteristics, values and typologies which contribute to the potential of a country,through cultural events can intertwine continuously.

The revitalization of Indonesian cultural identity is carried out to build awareness of Indonesian cultural identity. National identity as the value of community identity is built solidly and deeply internalized [12]. Based on the researcher's opinion, the urgency process of cultural revitalization in the border region includes the improvement of various physical aspects. This is because of temperature, humidity, rain, biological growth [13], so that the cultural heritage is threatened and requires proactive action[14]. This action has an impact on creativity and innovation by means of empowering local communities to improve the economy through tourism [2], through the positive attitudefrom the local communities[15].

Cultural revitalization is a short-term strategy that is intended to encourage an increase in cultural sustainability. Through an action plan to maintain, enhance local wisdom and preserve culture [16]. For this reason, it is necessary to improve and enhance the socio-cultural aspects and the environmental aspects as well as human resources. These are done as a means to counteract globalization so that the community, especially the younger generation, has empathy and sensitivity to the social and cultural phenomena that have occurred. A Long-term strategy is carried out through heritage registration and documentation [17], the revitalization done, namely the revitalization of artifacts from ancient cultural works (border museum), natural resources (NR), human resources (HR), local wisdom and concentric study on the meaning of dance of art and culture.

The local policy owned by the Salako and Bakati culture community has a high value in nature conservation, innovation, and creativity to improve the economy of the local community, the development of ecotourism with a conceptual model, [18]so that the culture must be maintained its preservation, through local cultural education in the school curriculum [19] the realization of nationalism in the border region [20], and as a function to bridge the two countries namely Indonesia and Malaysia by the revitalization of traditional arts and soft diplomacy, [21]. By conducting revitalization will answer the problem and carried out a strategic renewal in preserving the culture of Salako and Bakati '. In the revitalization, there are obstacles and challenges, namely Social Capital (social capital that bridges HR), Institutional, financial, infrastructure, networking, and information. The following are the conditions and the cultural potential which are urgent to be revitalized

Table: The Conditions of Cultural Potential which are Urgent Revitalization

\begin{tabular}{|l|l|c|c|}
\hline \multirow{2}{*}{ No } & \multirow{2}{*}{ Name (Type) Culture } & \multicolumn{2}{|c|}{ Condition } \\
\hline & & Everlasting & Eroded \\
\hline I & Type of customs & & \\
\hline & Sansam & & $\checkmark$ \\
\hline & Kantoong & $\checkmark$ & \\
\hline & Rice Harvest & $\checkmark$ & \\
\hline & Besamsam Kampung & & $\checkmark$ \\
\hline & Koncong & $\checkmark$ & \\
\hline & Naik Dango & $\checkmark$ & \\
\hline & Ngabayan & $\checkmark$ & \\
\hline & Tumpi & & $\checkmark$ \\
\hline & Bontong & $\checkmark$ & \\
\hline & Totong & $\checkmark$ & \\
\hline & Weaving & $\checkmark$ & \\
\hline & Bapantun & & $\checkmark$ \\
\hline & Pencak Silat & & $\checkmark$ \\
\hline & Sculpture & $\checkmark$ & \\
\hline & Tattooed & & $\checkmark$ \\
\hline & Gasing & & $\checkmark$ \\
\hline & Chopsticks & & \\
\hline II & Philosophical & & \\
& Morality in \\
& Community Life & & $\checkmark$ \\
\hline & Tumpi' adding & & $\checkmark$ \\
\hline & Cucur & & \\
\hline
\end{tabular}




\begin{tabular}{|c|c|c|c|}
\hline & Belenggang/besiak & & $\checkmark$ \\
\hline & Mutual assistance & & $\checkmark$ \\
\hline & Nyanggahan & & $\checkmark$ \\
\hline & BesamborBaconteng & & \\
\hline & Bakayo & & \\
\hline & Bari' & & \\
\hline & Nari'u & & \\
\hline & Hunting & & \\
\hline III & $\begin{array}{l}\text { Conditions of the } \\
\text { Ritual Place }\end{array}$ & & \\
\hline & $\begin{array}{l}\text { Pabuisan } \\
\text { (TempatPantak) }\end{array}$ & $\checkmark$ & $\checkmark$ \\
\hline & Betang House & & $\checkmark$ \\
\hline & Tempayan & & \\
\hline & Gong & $\checkmark$ & $\checkmark$ \\
\hline & Dalu & $\checkmark$ & $\checkmark$ \\
\hline & Pantak & $\checkmark$ & \\
\hline & Mandau & $\checkmark$ & $\checkmark$ \\
\hline & Clothes for Ritual & & \\
\hline
\end{tabular}

Source: FGD

\subsection{The Importance of (Benefit) the Revitalization of Border Local Culture}

The revitalization of local border culture is an activity that allows local culture to be able to answer the challenges from the era and life today. By making its bushel measurement tool (in Bahasa gantangpenakar) are humanizing human, life, and society who are especially in the border region with Malaysia. This action is a follow-up step that follows the action of preservation that is data collection (registration) and the introduction of the cultural products from the previous generation "to fight the forgetfulness and restore the collective memory of a group of the community". Therefore, the community force afterward today and in the future will not become a rootless force or empty force. If it stops only as preservation and considers the local culture as the work or the product from the previous generations, then it is feared that the community will live to drag themselves back to the past so that it will be inundated in a total of adversity mud. The importance of planting cultural values among the citizens in the border region in order not to be expired and the history of the same fate among border citizens and ending poverty by increasing the welfare of the local community.

The Digital device is an important thing so that each historical value from an object can be told and can be accessed through the internet as a benefit of revitalization and the process of maintaining and defending aesthetic, historical, scientific and social values which are useful for the past, the present and the future generations, including maintenance which really depends on the conditions such as preservation, restoration, reconstruction, adaptation (revitalization) and combination. The aim of maintenance is to provide continuous protection and safeguarding of all physical materials from the place, to maintain the desired condition of the building. Type of routine maintenance work can also be in the form of repairing. The repairing activity includes restoration and reconstruction and must be treated accordingly. The damages that must be repaired can be caused by natural processes, such as fragility, weathering, dull or usage processes, such as scratches, breakages, etc. [22].

\section{CONCLUSION}

Revitalization, as part of a travel process of a nation, preservation or conservation and effort to strengthen the identity of border region which can be determined as issues of strategic policy. Some benefits for border community are:

Identity and Sense of Place of Historical heritage, artworks, and various local wisdom are the links between socio-cultural civilization with the past, connecting and distinguishing the socio-cultural conditions of Indonesia and Malaysia in a particular place.

The architectural value which becomes one of the reasons to preserve the environment and the historical building in the border region is its intrinsic value as artworks that can be in the form of high achievement results, for example, like laggam or certain arts that become the landmark of a place. Rationally, the benefits of cultural revitalization will make the dynamics of border community which are generally still less prosperous, limited infrastructure and public facilities. 
International Journal of Social Science (IJSS)

Vol.1 Issue.5 February 2022, pp: 569-574

ISSN: 2798-3463 (Printed) | 2798-4079 (Online)

DOI: https://doi.org/10.53625/ijss.v1i5.1296

Space Conflict Resolution, the development of border community civilization in Sambas Regency which borders with Kuching Malaysia is certainly inseparable from the sentiment and jealousy feeling which then can cause conflict triggered by many things such as boundaries, natural resources, and culture. Therefore, from a geopolitical perspective, the revitalization of the Indonesian archipelago culture in the border region is the vanguard for maintaining the security and the integrity of the Unitary of the Republic of Indonesia.

\section{RECOMMENDATION}

The Agenda of Local cultural revitalization policy can be done through various channels. (1). The first channel is academic education which needs to be explored and identified towards the various rich treasures of our local culture that are still contained in oral traditions, to do the codification of existing customary institutions. At the same time, a critical, respectful and reflective review of traditional values is carried out to explore and to state which one is suitable to be applied and which need to be adjusted to current needs.

In the process of codifying the traditional heritage, we need an alignment towards the truth of the history of local culture in the diversity of our society. In this case, it needs to be revitalized to a general tendency to hold on to a dominant culture needs, yet on the contrary, it must be open to various alternatives from small narratives as the sources of cultural history that have been certain items which also contain certain truths.

It needs to be explored and reformulated a new cultural vision of border region which becomes a common ground / common values / common culture for all communities in the border region. The parallelism and cultural similarity approaches are used with the intention to find a meeting point in the various heritages of customary institutions within each Indonesian-Malaysian border community that is similar and parallel to its cultural meaning. A synthetic study carried out to elaborate and integrate various aspects and customary values that are similar/parallel meaning into a common/ shared value that can be agreed to become the local cultural value of Sambas Regency.

\section{REFERENCE}

[1] H. S. M. Hasan, L. A. Wahab, D. Ismail, and H. S. M. Hasan, "Preliminary study on authenticity in adaptive reuse of heritage building in ipoh, malaysia," Int. J. Recent Technol. Eng., vol. 7, no. 6, pp. 295-300, 2019.

[2] D. Cahyaningrum, "Community Empowerment Based Local Wisdom In Tourism Of Bajo Community, Wakatobi,” Int. J. Sci. Technol. Res., vol. 6, no. 11, pp. 196-201, 2017.

[3] E. B. Tylor, Primitive Culture, Vol 2 (7th ed.)., 7th ed., vol. 2. New York: Brentano's, 1924.

[4] C. A. van Peursen, Strategi Kebudayaan, 2nd ed. Yogyakarta: Kanisius, 2000.

[5] P. M. Barone and C. Ferrara, "The past beneath the present: GPR as a scientific investigation for archaeology and cultural heritage preservation," Int. J. Conserv. Sci., vol. 8, no. 4, pp. 581-588, 2017.

[6] M. N. Tamalene and M. H. I. Almudhar, "Local knowledge of management system of forest ecosystem by Togutil Ethnic group on Halmahera Island, Indonesia: Traditional utilization and conservation," Int. J. Conserv. Sci., vol. 8, no. 3, pp. 497-508, 2017.

[7] S. Gafur, "Membangun Transparansi Melalui Partisipasi Publik di Kawasan Perbatasan Kalimantan Barat 'Kasus Kabupaten Sanggau dan Kabupaten Sambas," Universitas Tanjungpura dengan Kemitraan Jakarta dan Uni Eropa , Pontianak, 2006.

[8] A. Elyamani, M. S. El-Rashidy, M. Abdel-Hafez, and H. Gad El-Rab, "A contribution to the conservation of 20th century architectural heritage in Khedival Cairo," Int. J. Conserv. Sci., vol. 9, no. 1, pp. 55-70, 2018.

[9] M. A. Rokhimawan, "The integration of science and culture on indonesian archipelago kliwonan around masjid and buyut trusmi's tombs in cirebon," Int. J. Sci. Technol. Res., vol. 8, no. 8, pp. 1073-1080, 2019.

[10] Martinus Marthin, B. Suni, and H. Sujaie, "Sosial Budaya Perladangan Dayak Kerabat di Desa Tapang Perodah Kecamatan Sekadau Hulu Kabupaten Sekadau," J. Tesis PMIS-UNTAN-PSS-2012, pp. 1-10, 2012.

[11] E. Coates, "The poetics of physics in dance," PAJ - J. Perform. Art, vol. 39, no. 2, pp. 7-21, May 2017.

[12] A. S. Mubah, "Revitalisasi Identitas Kultural Indonesia di Tengah Upaya Homogenisasi Global," Glob. dan Strateg., vol. Edisi Khusus, pp. 251-260, 2011.

[13] D. Kumar, J. Prasad, A. K. Pandey, and M. K. Upadhyay, "A scientific approach to preservation of cultural heritage - Sib Sagar (Assam) centrally protected monument," Int. J. Conserv. Sci., vol. 9, no. 2, pp. 291-300, 2018.

[14] D. Mansir, N. Kasim, and I. S. Mat Radzuan, "An exploration of Disaster Risk to Cultural Heritage assets: Towards effective conservation," Int. J. Conserv. Sci., vol. 9, no. 3, pp. 523-536, 2018.

[15] J. Pollard and R. D. Rodriguez, "Tourism and torremolinos. Recession or reaction to environment?," Tour. Manag., vol. 14, no. 4, pp. 247-258, 1993.

[16] A. T. Subadyo and D. Poerwoningsih, "Preservation of tengger tribe yard landscape in the enclave of Bromo 
Tengger Semeru National Park, Indonesia," Int. J. Conserv. Sci., vol. 10, no. 3, pp. 507-518, 2019.

[17] A. V. Tache, I. C. A. Sandu, O. C. Popescu, and A. I. Petrişor, "UAV solutions for the protection and management of cultural heritage. Case Study: Halmyris archaeological site," Int. J. Conserv. Sci., vol. 9, no. 4, pp. 795-804, 2018.

[18] E. T. Fitriasari, N. Kistanto, Yuwanto, and T. Yuwono, "Policy Strategy Beyond Eco Tourism Development," Econ. Dev. Anal. J., vol. 8, no. 3, pp. 264-278, 2019.

[19] M. H. I. Al Muhdhar et al., "Local Wisdom-Based Conservation Ethics of Tabaru Traditional Community on Halmahera Island ," Int. Conserv. Sci., vol. 10, no. 3, pp. 533-542, 20191.

[20] P. G. Yanti, N. Ibrahim, and F. Rahman, "Nationalism study of primary students in the border area of West Kalimantan-Indonesia and Malaysia," Int. J. Sci. Technol. Res., vol. 8, no. 12, pp. 682-686, 2019.

[21] A. M. Irianto, "Kesenian Tradisional Sebagai Sarana Strategi Kebudayaan di Tengah Determinasi Teknologi Komunikasi | Irianto | Nusa: Jurnal Ilmu Bahasa dan Sastra," NUSA, vol. 12. No 1, Feb. 2017.

[22] D. R. T. Busono, "ESKURSI PRESERVASI, KONSERVASI, RENOVASI PADA PEMELIHARAAN BANGUNAN DI SINGAPURA DAN MALAYSIA.” 2009. 